Penerbit:

Program Studi Magister Ilmu Kesehatan Masyarakat, Program Pascasarjana, Universitas Sam Ratulangi

Indonesian Journal of Public Health and Community Medicine is indexed by Google Scholar and licensed under a Creative Commons Attribution 4.0 International License.

\title{
Analisis Faktor-Faktor Yang Berhubungan Dengan Stres Kerja Pada Pegawai Rumah Sakit Mata Provinsi Sulawesi Utara
}

\author{
Esra Margaret Singal ${ }^{1 *}$, Aaltje Ellen Manampiring², dan Jeini Ester Nelwan ${ }^{3}$ \\ 1. Program Studi Ilmu Kesehatan Masyarakat, Program Pascasarjana Universitas \\ Sam Ratulangi \\ 2. Fakultas Kedokteran Universitas Sam Ratulangi \\ 3. Fakultas Kesehatan Masyarakat Universitas Sam Ratulangi \\ *E-mail: esramargaret@gmail.com
}

\begin{abstract}
Abstrak
Latar Belakang: Stres kerja merupakan hal yang sangat menggangu pekerjaan. Stres akibat kerja secara khusus mengakibatkan terjadinya penurunan produktivitas kerja seperti performansi pekerja yang rendah, meningkatnya angka absensi, menurunnya moral kerja, meningkatnya turnover pekerja yang dapat menyebabkan kehilangan banyak waktu kerja menyebabkan biaya kompensasi pekerja meningkat modal. Tujuan penelitian ini yaitu untuk menganalisis faktorfaktor yang berhubungan dengan stres kerja pada pegawai Rumah Sakit Mata Provinsi Sulawesi Utara. Metode Penelitian: Penelitian ini termasuk studi observasional dengan rancangan penelitian cross sectional study. Populasi dalam penelitian ini adalah seluruh pegawai Rumah Sakit Mata Provinsi Sulawesi Utara. Sampel dalam penelitian adalah total populasi yang berjumlah 70 orang pegawai. Variabel dalam penelitian ini yaitu umur, status pernikahan, pendapatan, masa kerja dan beban kerja, dengan variabel dependen yaitu stres kerja. Data hasil penelitian dianalisis secara univariat, bivariat dan multivariat dan perhitungan statisik chisquare. Penyajian data dibuat dalam bentuk tabel dan narasi. Hasil Penelitian: Hasil penelitian yang menunjukan bahwa terdapat hubungan yang bermakna antara umur dengan stres kerja dengan nilai $p=0,031$, terdapat hubungan yang bermakna antara masa kerja dengan stres kerja dengan nilai $p=0,004$, terdapat hubungan yang bermakna antara beban kerja dengan stres kerja dengan nilai $p=0,003$, tidak terdapat hubungan yang bermakna antara status pernikahan dengan stres kerja dengan nilai $p=0,077$ dan tidak terdapat hubungan yang bermakna antara pendapatan dengan stres kerja dengan nilai $p=0,473$. Hasil analisis secara multivariat menunjukan beban kerja ( $p=0,002 ;$ OR $=21,667$ merupakan faktor yang paling dominan berpengaruh terhadap stres kerja pada pegawai Rumah Sakit Mata Provinsi Sulawesi Utara. Kesimpulan: Kesimpulan penelitian ini yaitu umur, masa kerja dan beban kerja merupakan faktor yang berhubungan dengan stress kerja. faktor yang paling dominan berpengaruh terhadap stres kerja pegawai adalah beban kerja.
\end{abstract}

Kata Kunci: Stres kerja; Pegawai; Rumah Sakit 


\section{Abstract}

Background: Job stress is a very disruptive thing to work. Work-induced stress in particular results in a decrease in work productivity, such as low worker performance, increased absenteeism, decreased work morale, increased worker turnover which can cause the loss of a lot of working time causing the cost of compensation for workers to increase in capital. The purpose of this study was to analyze the factors associated with work stress on the employees of the Eye Hospital of North Sulawesi Province. Methode: This study was an observational study with a cross sectional study design. The population in this study were all employees of the Eye Hospital of North Sulawesi Province. The sample in this study was a total population of 70 employees. The variables in this study were age, marital status, income, years of service and work load, with the dependent variable being work stress. The research data were analyzed using univariate, bivariate and multivariate analysis and chi-square statistical calculations. Presentation of data is made in table and narrative form. Result: The results showed that there was a significant relationship between age and work stress with $p$ value $=0.031$, there was a significant relationship between tenure and work stress with a value of $p=0.004$, there was a significant relationship between workload and work stress with $p=0.003$, there is no significant relationship between marital status and work stress with a value of $p=0.077$ and there is no significant relationship between income and work stress with a value of $p=0.473$. The result of multivariate analysis showed that workload $(p=0.002 ;$ OR $=21.667)$ was the most dominant factor affecting work stress on the employees of the Eye Hospital of North Sulawesi Province. Conclusion: The conclusion of this study is that age, years of service and workload are factors that are associated with work stress. The most dominant factor affecting employee work stress is workload.

Key words: Job stress; Employee; Hospital

\section{PENDAHULUAN}

Stres kerja merupakan hal yang sangat menggangu pekerjaan. Jika karyawan mengalami stres kerja, maka pekerjaan karyawan tersebut juga akan terganggu. Terjadinya stres akibat kerja secara khusus akan dapat terjadinya penurunan produktivitas kerja seperti performansi pekerja yang rendah, meningkatnya angka absensi, menurunnya moral kerja, meningkatnya turnover pekerja yang dapat menyebabkan kehilangan banyak waktu kerja menyebabkan biaya kompensasi pekerja meningkat modal (Tarwaka (2015). Tingkat stres seseorang bergantung pada kemampuan yang dirasakan pada diri seseorang, kepercayaan diri, ketakutan dan kegagalan seseorang (Hamali, 2018).

Survei yang dilakukan oleh Health and Safety Executive (HSE) menyatakan bahwa stres dan depresi terkait pekerjaan pada tahun 2017/2018 adalah 595.000 kasus dengan tingkat prevalensi 1.800 per 100.000 pekerja. Stres dan depresi karena pekerjaan juga menyumbangkan $44 \%$ dari semua kasus gangguan kesehatan karena pekerjaan dan $57 \%$ dari ketidakhadiran di kantor karena sakit (HSE, 2018).

Data hasil Riset Kesehatan Dasar (Riskesdas) tahun 2018 menunjukan bahwa prevalensi penduduk Indonesia pada penduduk umur $>15$ tahun yang mengalami gangguan mental emosional atau stres 37.728 orang $(9,8 \%)$. Provinsi dengan prevalensi gangguan mental emosional atau stres tertinggi adalah Sulawesi tengah sebesar 11,6\%, dan yang paling terendah terdapat di Lampung 1,2\%. Prevalensi penduduk Sulawesi Utara yang mengalami gangguan mental emosional atau stres sebesar 10,3\%. Angka ini sudah berada di atas data nasional (9,8\%). Data hasil Riskesda memang tidak menggambarkan bahwa gangguan mental atau stres yang terjadi adalah akibat kerja. Oleh 
karena itu, seharusnya menjadi perhatian karena prevalensi gangguan mental atau stres di Sulawesi utara sudah di atas data nasional dan jika masalah ini tidak diatasi dengan sunguh-sunguh bahkan tidak mungkin masalah ini akan menjadi besar kedepannya.

Penelitian yang di lakukan Reppi (2019) tentang Faktor-faktor resiko kerja pada ASN menunjukan bahwa terdapat hubungan antara konflik interpersonal, beban kerja dan dukungan sosial dengan dengan stres kerja pada ASN di salah satu instansi pemerintahan Provinsi Sulawesi Utara. Penelitian yang dilakukan Parslow (2004) pada pegawai pemerintah Australia menunjukkan bahwa stres pada pegawai pemerintah wanita meningkat disebabkan oleh jam kerja dan kontrol terhadap pekerjaan sedangkan pada pegawai pemerintah pria disebabkan oleh ketidakmampuan dalam melakukan pekerjaan. Penelitian yang sering dilakukan lebih memfokuskan pada bidang industri, sementara itu dengan mempertimbangkan kemungkinan terjadinya stres pada bidang lain seperti pemerintahan maka perlu dilakukan juga penelitian di bidang pemerintahan.

Penelitian ini dilakukan pada pegawai di Unit Pelaksana Teknis Daerah (UPTD) Rumah Sakit Mata Provinsi Sulawesi Utara. Rumah Sakit Mata ini yang sebelumnya merupakan sebuah Balai Kesehatan Mata Masyarakat Provinsi Sulawesi Utara. Rumah Sakit Mata ini merupakan satu-satunya RS Khusus mata yang ada di Provinsi Sulawesi Utara yang sudah terakreditasi dan juga merupakan Pusat Rujukan Indonesia Timur Bagian Utara baik peserta BPJS Kesehatan maupun Umum. Rumah Sakit ini terletak di Ibukota Provinsi Sulawesi Utara yaitu Kota Manado dan sebagai satu-satunya Rumah Sakit Mata yang ada, maka jumlah kunjungan pasien di Rumah Sakit ini terus meningkat dalam lima tahun terakhir jumlah kunjungan tahun 2015 berjumlah 22.301 orang dan pada 2019 berjumlah 44.798 orang (Profil RS, 2019). Tujuan penelitian ini yaitu untuk menganalisis faktor-faktor yang berhubungan dengan stres kerja pada pegawai Rumah Sakit Mata Provinsi Sulawesi Utara.

\section{METODE PENELITIAN}

Penelitian ini termasuk studi observasional dengan rancangan penelitian cross sectional study. Populasi dalam penelitian ini yaitu seluruh pegawai Rumah Sakit Mata Provinsi Sulawesi Utara. Sampel dalam penelitian adalah total populasi yang berjumlah 70 orang pegawai. Variabel dalam penelitian ini yaitu umur, status pernikahan, pendapatan, masa kerja dan beban kerja, dengan variabel dependen yaitu stres kerja. Data hasil penelitian dianalisis secara univariat, bivariat dan multivariat dan perhitungan statisik chi-square. Penyajian data dibuat dalam bentuk tabel dan narasi.

\section{HASIL DAN PEMBAHASAN}

\section{Analisis univariat}

Hasil penelitian untuk karakteristik responden dan karakteristik variable dapat dilihat pada Tabel 1. Data pada Tabel 1 menunjukkan bahwa umur responden sebanyak 14 responden $(20 \%)$ berumur lebih dari 43 tahun sedangkan 56 responden $(80 \%)$ berumur kurang dari 43 tahun. Depertemen Kesehatan (2009) membagi usia dalam kategori dewasa akhir, lansia awal dan dewasa awal yang juga merupakan usia produktif. . Penelitian yang dilakukan oleh Ramadhan (2017) pada Karyawan di Biro Administrasi Umum dan Keuangan Universitas Dipenogoro menunjukkan bahwa sebagian besar responden berusia 31-40 tahun yaitu sebanyak 33,3\% dan usia 41-50 tahun yaitu sebanyak 30\%. Penelitian yang dilakukan oleh Sorongan (2018) pada Pegawai di Dinas Kesehatan Kota Manado mendapatkan hasil bahwa sebagian besar responden berusia 2635 tahun yaitu sebanyak 43 orang (51,8\%). Menurut Kumbadewi (2016), usia produktif 
seorang pekerja berada dalam rentang 15 sampai 65 tahun sehingga dapat terlihat responden dalam penelitian ini tergolong usia produktif. Usia seseorang mempengaruhi tingkat stresnya, semakin meningkat usia maka semakin tinggi juga tingkat stresnya dan jika usia pekerja memasuki lanjut usia maka stresnya lebih meningkat karena dipengaruhi

Tabel 1. Hasil analisis unixariat

\begin{tabular}{clcc}
\hline Karakteristik & \multicolumn{1}{c}{ Kelompok } & Jumlah (n) & Persentase (\%) \\
\hline \multirow{2}{*}{ Jenis kelamin } & Laki-laki & 15 & 21.4 \\
& Perempuan & 55 & 78.6 \\
\hline \multirow{4}{*}{ Tingkat } & SPK & 1 & 1.4 \\
Pendidikan & S1 & 2 & 2.9 \\
& S2 & 48 & 68.6 \\
& Spesialis & 12 & 17.1 \\
& Dokter & 7 & 10 \\
\hline \multirow{3}{*}{ Jabatan } & Perawat & 16 & 22.9 \\
& Tenaga Admin & 36 & 51.4 \\
& Apoteker/Assist & 14 & 20 \\
\multirow{2}{*}{ Umur (Tahun) } & $>43$ Tahun & 4 & 5.7 \\
& $\leq 43$ Tahun & 14 & 20 \\
\multirow{2}{*}{ Status Pernikahan } & Menikah & 56 & 80 \\
& Belum Menikah & 62 & 88.6 \\
\hline \multirow{2}{*}{ Masa Kerja } & Lama $\geq 5$ tahun & 8 & 11.4 \\
& Baru $<5$ tahun & 12 & 17,1 \\
& Tinggi $>10$ jt & 58 & 82,9 \\
\hline \multirow{2}{*}{ Pendapatan } & Menengah 5-10 jt & 20 & 28.6 \\
& Rendah $<5$ jt & 40 & 57.1 \\
& Ringan & 10 & 14.3 \\
\hline \multirow{2}{*}{ Beban Kerja } & Sedang & 12 & 17.1 \\
& Berat & 42 & 60 \\
\hline \multirow{2}{*}{ Stres Kerja } & Tinggi & 16 & 22.9 \\
& Rendah & 38 & 54.3 \\
\hline & Total & $\mathbf{7 0}$ & 45.7 \\
\hline
\end{tabular}

oleh beberapa faktor seperti fisik dan status kesehatannya.

Frekuensi jenis kelamin pegawai yang menjadi responden pada penelitian ini adalah laki-laki sebanyak $21,4 \%$ dan perempuan $78,6 \%$. Penelitian serupa di lakukan Sorongan (2018) dengan hasil bahwa mayoritas responden adalah perempuan. Hasil yang serupa dalam penelitian yang dilakukan oleh Reppi (2019) tentang Stres Kerja pada ASN menunjukkan bahwa jenis kelamin perempuan lebih dominan dibandingkan jenis kelamin laki-laki. Peneliti menjadikan seluruh pegawai di Rumah Sakit Mata Provinsi Sulawesi Utara sebagai responden sehingga peneliti tidak bisa menentukan jumlah antara laki-laki dan perempuan, melainkan seluruh jumlah pegawai laki-laki dan perempuan yang kemudian muncul sebagai persentase jenis kelamin. Jenis kelamin merupakan salah satu faktor yang mempengaruhi kemampuan kerja seorang tenaga kerja. Laki-laki dan perempuan mempunyai perbedaan dalam kemampuan fisiknya dan kekuatan kerja ototnya (Suma'mur, 2014). 
Pendidikan terakhir responden yang didapatkan dari hasil uji univariat mayoritas pegawai di Rumah Sakit Mata Provinsi Sulawesi Utara telah menempuh pendidikan hingga Sarjana yaitu sebanyak 68,6\%. Dalam perekrutan pegawai pemerintahan biasanya pendidikan terakhir yang disyaratkan adalah Sarjana, oleh karena itu kemungkinan besar hal tersebut yang menyebabkan mayoritas responden memiliki latar pendidikan sarjana. Latar belakang pendidikan ini juga yang nantinya berpengaruh jabatan responden. Hasil uji menunjukkan frekuensi jabatan dari seluruh responden adalah perawat sebanyak $51,4 \%$, dokter sebanyak $22,9 \%$, tenaga admin sebanyak $20 \%$ dan tenaga admin sebanyak $5,7 \%$. Penentuan jabatan dari responden menyesuaikan dengan tugas dan fungsi dari jabatan yang tersebut dan orang yang akan mengisi jabatan tersebut tentunya dilihat dari latar belakang pendidikan yang sesuai dengan tugas dan fungsi yang akan dilaksanakan.

Semakin tinggi tingkat pendidikan seseorang maka semakin baik pula pola pikirnya dalam mencerna informasi-informasi yang dapat mendasari pola perilaku orang tersebut. Tingkat pendidikan bukan merupakan satu-satunya faktor yang mendukung pola pikir seseorang namun dengan tingginya tingkat pendidikan seseorang maka seseorang tersebut cenderung lebih mudah menerima perubahan yang bersifat baik sedangkan seseorang yang tidak memiliki dasar tingkat pendidikan yang berkelanjutan akan bersifat tertutup dan sulit untuk menerima perubahan perilaku tersebut (Ariwibowo, 2013).

Jabatan responden yang paling banyak dalam penelitian ini yaitu Perawat berjumlah 36 orang dengan presentase 51,4\%, kemudian Dokter 14 orang dengan presentase 22,9\%, Tenaga admin berjumlah 14 dengan presentase 20,0\% dan Apoteker/TTK berjumlah 4 orang dengan presentase $5,7 \%$. Hasil penelitian ini sejalan dengan penelitian yang dilakukan oleh Lendombela dkk (2017) yang menunjukan bahwa sebagian besar pegawai adalah perawat yaitu berjumlah $83.8 \%$. Perawat merupakan profesi khusus bertugas memberikan asuhan keperawatan dan bertanggung jawab atas kondisi peningkatan kesehatan, pelayanan bagi pasien serta pencegahan penyakit. Setiap rumah sakit pasti sangat membutuhkan perawat profesional yang dapat meningkatkan kualitas pelayanan Rumah Sakit. berdasarkan uraian di atas jabatan berpengaruh terhadap kinerja pegawai, kelelahan kerja sampai stres kerja (Mauritis, 2013). 
Tabel 2. Analisis Bivariat

\begin{tabular}{|c|c|c|c|c|c|c|c|c|}
\hline \multirow{3}{*}{ Umur } & \multicolumn{4}{|c|}{ Stres Kerja } & \multicolumn{2}{|c|}{ Total } & \multirow{3}{*}{ OR } & \multirow{3}{*}{$p$ value } \\
\hline & \multicolumn{2}{|c|}{ Tinggi } & \multicolumn{2}{|c|}{ Rendah } & \multirow{2}{*}{$\mathrm{n}$} & \multirow{2}{*}{$\%$} & & \\
\hline & $\mathrm{n}$ & $\%$ & $\mathrm{n}$ & $\%$ & & & & \\
\hline Beresiko & 4 & 28,6 & 10 & 71,4 & 14 & 100 & & \\
\hline $\begin{array}{l}\text { Kurang } \\
\text { Bersike }\end{array}$ & 34 & 60,7 & 32 & 39,3 & 66 & 100 & 0,259 & 0,031 \\
\hline Jumlah & 38 & 54,3 & 32 & 45,7 & 70 & 100 & & \\
\hline \multicolumn{9}{|c|}{$\begin{array}{l}\text { Status } \\
\text { Pernikahan }\end{array}$} \\
\hline Menikah & 36 & 58,1 & 26 & 41,9 & 62 & 100 & \multirow{3}{*}{4,514} & \multirow{3}{*}{0,077} \\
\hline $\begin{array}{l}\text { Belum } \\
\text { Menikah }\end{array}$ & 2 & 25 & 6 & 75 & 8 & 100 & & \\
\hline Jumlah & 38 & 54,3 & 32 & 45,7 & 70 & 100 & & \\
\hline \multicolumn{9}{|c|}{ Masa Kerja } \\
\hline Lama & 2 & 16,7 & 10 & 83,3 & 12 & 100 & \multirow{3}{*}{0,122} & \multirow{3}{*}{0,004} \\
\hline Baru & 36 & 62,1 & 22 & 37,9 & 58 & 100 & & \\
\hline Jumlah & 38 & 54,3 & 32 & 45,7 & 70 & 100 & & \\
\hline \multicolumn{9}{|c|}{ Pendapatan } \\
\hline Tinggi & 10 & 50,0 & 10 & 50,0 & 20 & 100 & \multirow{4}{*}{0,000} & \multirow{4}{*}{0,473} \\
\hline Menengah & 24 & 60,0 & 16 & 40,0 & 40 & 100 & & \\
\hline Rendah & 4 & 40,0 & 6 & 60,0 & 10 & 100 & & \\
\hline Jumlah & 38 & 54,3 & 32 & 45,7 & 70 & 100 & & \\
\hline \multicolumn{9}{|c|}{ Beban Kerja } \\
\hline Ringan & 2 & 16,7 & 10 & 83,3 & 12 & 100 & \multirow{4}{*}{0,000} & \multirow{4}{*}{0,003} \\
\hline Sedang & 23 & 54,8 & 19 & 45,2 & 42 & 100 & & \\
\hline Berat & 13 & 81,2 & 3 & 18,8 & 16 & 100 & & \\
\hline Jumlah & 38 & 54,3 & 32 & 45,7 & 70 & 100 & & \\
\hline
\end{tabular}

\section{a. Hubungan antara umur dengan stres kerja}

Penilaian terhadap umur pada responden dipenelitian ini dibagi menjadi dua yaitu responden yang beresiko dengan usia $>43$ tahun dan responden yang kurang bereriko dengan usia $\leq 43$ tahun. Hasil penelitian menunjukkan bahwa sebanyak 60,7 $\%$ responden termasuk dalam umur yang kurang beresiko dan $28,6 \%$ termasuk dalam umur yang beresiko. Hasil tabulasi silang menunjukkan responden pada usia yang beresiko yang mengalami stres kerja tinggi sebanyak 4 responden dengan presentase $28,6 \%$ dan yang mengalami stres kerja rendah sebanyak 10 dengan presentase $71,4 \%$. Robbins (2007) menyatakan bahwa hubungan antara usia dan kinerja seseorang akan menjadi masalah dimasa mendatang. Para pekerja yang lebih tua memiliki kualitas positif pada pekerjaan mereka, khususnya pengalaman, penilaian, etika kerja yang kuat dan komitment terhadap kualitas. Hasil penelitian juga menunjukkan 29,4\% responden termasuk dalam umur yang kurang beresiko mengalami stres kerja tinggi dan $70,6 \%$ yang mengalami stres kerja rendah. Kejadian stres kerja pada usia yang 
kurang beresiko terjadi karena walaupun berada pada usia kurang beresiko tetapi terdapat faktor lain yang mempengaruhinya seperti penurunan kondisi fisik seiring dengan pertambahan usia.

Hasil uji bivariat untuk varibel umur dalam hubungannya dengan stres kerja menunjukkan hasil $\rho$ value sebesar 0,031 . Hal ini berarti terdapat hubungan yang signifikan antara umur dengan stres kerja dengan risiko 0,2 kali lebih besar pada umur yang beresiko dibandingkan dengan umur yang kurang beresiko. Hasil ini sejalan dengan penelitian yang dilakukan oleh Zulkifli (2019) tentang Hubungan Usia, Masa Kerja dan Beban Kerja Dengan Stres Kerja Pada Karyawan Service Well Company PT. ELNUSA TBK Wilayah Muara Badak. Penelitian ini menunjukkan bahwa terdapat hubungan antara umur dengan stress kerja. Namun, penelitian yang dilakukan oleh Zuklkifli dkk ini menjadikan usia yang lebih tua sebagai faktor yang paling beresiko terhadap stres kerja. Hal ini disebabkan oleh adanya pekerjaan serta tugas yang lebih besar terhadap pegawai yang usianya $>40$ tahun.

Hasil yang berbeda ditunjukkan oleh penelitian yang dilakukan oleh Fuada (2017). Penelitian dilakukan dengan tema Faktor-faktor yang berhubungan dengan Stres Kerja pada Perawat Kamar Bedah di Instalasi Bedah Sentral RSUD K. R.M. T. Wongsonegoro Semarang yang hasilnya menunnjukkan bahwa tidak terdapat hubungan antara umur dengan stres kerja. Perbedaan hasil disebabkan oleh adanya persamaan jenis pekerjaan yang dilakukan oleh responden pada penelitian yang dilakukan oleh Fuada dkk ini. Hal tersebut membuat umur menjadi tidak berpengaruh karena baik usia tua dan usia muda mempunyai jenis pekerjaan yang sama. Sedangkan pada penelitian yang dilakukan oleh peneliti, responden dengan usia beresiko dan kurang beresiko memiliki jenis pekerjaan yang berbeda.

\section{b. Hubungan antara status pernikahan dengan stres kerja}

Status pernikahan adalah salah satu variable yang diuji pada penelitian ini. Status perkawinan termasuk dalam salah satu faktor yang menyebabkan stress kerja. Hasil uji univariat menunjukkan bahwa terdapat $88,6 \%$ responden yang sudah menikah dan sisanya $11,4 \%$ belum menikah. Hasil tabulasi silang menunjukkan dari $88,6 \%$ responden yang sudah menikah, terdapat 58,1\% yang mengalami stres kerja tinggi dan 41,9\% mengalami stres kerja rendah. Konflik pekerjaan dengan keluarga menjadi salah satu pemicu dalam status perkawinan yang dapat menyebabkan stres (Sari, 2015). Berdasarkan hasil uji bivariat didapatkan nilai signifikansi sebesar 0,077 . Hal ini berarti tidak terdapat hubungan antara status pernikahan dengan stress kerja.

Penelitian yang dilakukan oleh Vivian dkk (2017) tentang Stress of Singlehood: Marital Status, Domain-Specific Stress, and Anxiety in a National U.S. Sample dan penelitian yang dilakukan oleh Nagaruju dkk (2013) tentang "A Factor of Marital Status Highly Influencing on Stress of Women Employee's. ” A Case Study at Insurance Sector menunjukkan bahwa status pernikahan dapat berpegaruh terhadap stres yang dialami seseorang. Terdapat hal yang berbeda di mana responden pada penelitian ini tidak menjadikan masalah keluarga atau kehidupan pernikahan sebagai sesuatu hal yang menyebabkan stres terhadap pekerjaan mereka. Kehidupan pernikahan bisa saja menyebabkan stress terhadap kehidupan sosial responden tetapi hal tersebut tidak ikut mengganggu pekerjaan yang dilakukan oleh responden.

Penelitian lain yang sejalan dengan penelitian ini dilakukan oleh Yanto dkk tentang Faktor yang berhubungan dengan stress kerja pada perawat baru di semarang. Hasil penelitian menunjukkan bahwa tidak terdapat hubungan antara status 
perkawinan dengan stres kerja. Hal ini mungkin juga disebabkan oleh usia perkawinan, dimana semakin lama perkawinan dijalankan maka toleransi terhadap masalah dalam perkawinan semakin besar sehingga masalah-masalah yang timbul dalam perkawinan tidak terbawa dalam pekerjaan. Selain itu, stres kerja pada responden di penelitian ini kemungkinan besar dipengaruhi oleh variable-variabel lain diluar status perkawinan.

\section{c. Hubungan antara masa kerja dengan stres kerja}

Masa kerja merupakan lamanya orang bekerja yang dihitung dalam jangka waktu dan menyumbangkan tenaga pada perusahaan atau institusi tertentu (Tarwaka, 2015). Hasil uji univariat terhadap variabel masa kerja yaitu terdapat 82,9 \% responden yang baru bekerja $<5$ tahun dan $17,1 \%$ responden yang sudah bekerja selama $\geq 5$ tahun. Mayoritas responden baru bekerja selama kurang dari lima tahun. Karyawan dengan masa kerja yang lebih lama akan menyalurkan stres ke hal yang positif dalam bekerja. karyawan dengan masa kerja rendah lebih menyalurkan stres ke suatu hal negatif dalam kinerja yang mungkin mengakibatkan pengunduran diri secara suka rela. Berdasarkan teori akumulasi, semakin lama karyawan bekerja maka semakin tahan terhadap stres (Bradley, 2007). Pengalaman bekerja karyawan akan bertambah seiring bertambahnya masa kerjanya, sehingga karyawan dengan masa kerja yang tinggi akan mampu mengelola stres dengan baik. Dalam mengatasi stres, karyawan dengan masa kerja yang lebih lama akan memfokuskan perhatiannya kepada tugas yang sudah dipahami (Hunter \& Thatcher, 2007). Karyawan dengan masa kerja yang lebih lama tentu akan mampu bekerja dibawah tekanan dengan efektif apabila dibandingkan dengan karyawan yang mempunyai masa kerja rendah.

Hasil uji bivariat hubungan antara masa kerja dan stres kerja menunjukkan terdapat $62,1 \%$ responden dengan masa kerja yang baru atau $<5$ tahun mengalami stres kerja tinggi. Hal ini berarti sesuai dengan teori diatas yang mengatakan bahwa orang dengan masa kerja sedikit akan lebih berpotensi mengalami stres kerja. Nilai signifikansi yang dihasilkan dari uji hubungan antara keduanya yaitu 0,004 yang berarti terdapat hubungan antara masa kerja dengan stress kerja. Hasil ini sejalan dengan penelitian yang dilakukan oleh Fitri (2013) tentang Analisis Faktor-faktor yang berhubungan dengan kejadian Stres Kerja pada Karyawan Bank. Penelitian tersebut menunjukkan hasil bahwa terdapat hubungan antara masa kerja dengan stres kerja. Pekerja dengan masa kerja yang lebih lama akan memiliki pengalaman yang lebih banyak mengenai pekerjaan yang dilakukan. Pengalaman tersebut akan mendukung pekerjaan yang dilakukan oleh pekerja dan akan mengurangi stres yang ditimbulkan oleh pekerjaan. Dalam penelitian yang dilakukan oleh peneliti, responden yang mengalami stres kerja adalah responden yang memiliki masa kerja yang cenderung sedikit. Hal ini kemungkinan dikarenakan kurangnnya pengalaman dalam melakukan pekerjaan serta cara menyesuaikan diri dengan pekerjaan sehingga menyebabkan stres dengan pekerjaan yang dilakukan.

Penelitian dengan subjek berbeda yang dilakukan oleh Syabilah dkk (2015) juga menunjukkan hasil yang serupa. Penelitian yang dilakukan menjadikan pilot penerbangan sipil sebagai subjek penelitian tentang stres kerja dan hasilnya menunjukkan bahwa terdapat hubungan antara masa kerja dengan stress kerja. Hal ini sudah sangat jelas, bahwa profesi sebagai pilot sangat membutuhkan pengalaman yang banyak untuk dapat melakukan pekerjaan dengan baik. Demikian pula dengan penelitian yang dilakukan oleh peneliti, dimana sebagian besar berprofesi sebagai tenaga medis (dokter, perawat dan apoteker) yang juga membutuhkan pengalaman 
atau masa kerja yang lebih banyak untuk dapat menjalankan profesi dengan baik dan terhindar dari stres. Masa kerja yang banyak akan menjadikan seorang tenaga medis menjadi terampil dalam melakukan perkerjaan.

\section{d. Hubungan antara pendapatan dengan stres kerja}

Variabel pendapatan juga ikut diteliti pada penelitian ini, dimana telah diuji hubungannya dengan stres kerja. Hasil uji univariat menunjukkan bahwa sebagian besar responden memiliki pendapatan sebesar 5-10 juta rupiah yaitu sebanyak 60\%. Pendapatan yang dimaksud pada penelitian ini adalah hasil yang diterima oleh responden dari pekerjaannya atau usaha lainnya yang diukur dengan uang. Berdasarkan hasil uji bivariate didapatkan hasil nilai $\rho$ sebesar 0,473 . Hal ini berarti tidak terdapat hubungan yang signifikan antara pendapatan dengan stres kerja.

Penelitian serupa juga dilakukan oleh Sari dkk (2017) tentang faktor yang berhubungan dan stres kerja pada perawat di ruang rawat inap RSJ Provinsi Sulawesi Tenggara. Hasil dari penelitian tersebut juga mengemukakan bahwa tidak terdapat hubungan antara gaji/pendapatan dengan stres kerja. Jika dilihat dari jumlah gaji yang didapat oleh responden maka jumlah tersebut sudah berada di atas UMR daerah Sulawesi Utara. UMR menjadi tolak ukur akan sudah sesuai atau tidaknya jumlah upah yang diterima pekerja. Peneliti berpendapat bahwa seluruh responden pada penelitian yang dilakukan oleh peneliti sudah merasa puas dengan pendapatan yang dihasilkan oleh responden, sehingga hal tersebut tidak menjadi masalah jika dihubungkan dengan stres kerja. Hal lain yang mungkin menjadi alasan tidak adanya hubungan antara pendapatan dengan stres kerja pada penelitian yang dilakukan oleh peneliti adalah karena sebagian besar responden telah memilki pendapatan yang mencukupi sehingga tidak sebanding dengan jumlah responden yang memiliki pendapatan yang masih kurang.

\section{e. Hubungan antara beban kerja dengan stres kerja}

Hubungan beban kerja dengan stres kerja pada pegawai Rumah Sakit Mata Provinsi Sulawesi Utara dalam hal ini beban kerja yang dimaksud adalah kapasitas atau kemampuan pekerja dengan tuntutan yang harus dihadapi baik bersifat fisik atau mental (Hariyati, 2017). Hasil uji univariat menunjukkan bahwa sebanyak $60 \%$ responden mengalami beban kerja sedang dan sisanya sebanyak $40 \%$ mengalami beban kerja berat dan ringan. Hasil uji bivariat antara beban kerja dengan stres kerja menunjukkan hasil $\rho=0,003$ yang berarti terdapat hubungan antara beban kerja dengan stres kerja.

Hasil ini sejalan dengan penelitian yang dilakukan oleh Reppi dkk (2020) tentang Faktor Risiko Stres Kerja pada Aparatur Sipil Negara, dimana hasil yang didapatkan juga menunjukkan bahwa terdapat hubungan antara beban kerja dengan stres kerja. Pekerjaan yang melebihi kapasitas atau potensi diri pekerja menyebabkan mudah lelah dan bekerja dalam ketegangan tinggi (Anies, 2014). Hal ini disebabkan oleh adanya beban kerja yang melebihi kapasitas responden seperti adanya jumlah pasien yang banyak dan harus dilayani serta pekerjaan lainnya yang membuat responden merasa berat untuk melaksanakan sehingga juga menjadi faktor pemicu stres.

Penelitian lain yang sejalan dengan penelitian ini adalah yang dilakukan oleh peneliti adalah penelitian tentang Hubungan antara beban kerja dan stres kerja perawat IGD RSUD Kabupaten Semarang yang dilakukan oleh Haryanti dkk (2013). Hasil penelitian menunjukkan adanya hubungan antara beban kerja dengan stres kerja. Pekerjaan menjadi tenaga medis (dokter dan perawat) yang menjadi profesi dari mayoritas responden pada penelitian ini dan penelitian yang dilakukan oleh Haryati 
dkk menjadikan hasil ujinya serupa. Hal ini menunjukkan bahwa terdapat beban kerja yang besar yang dialami oleh responden pada kedua penelitian ini yang menjadi faktor penyebab terjadinya stress.

Tabel 3. Analisis regresi logistik terhadap stres kerja

\begin{tabular}{ccc}
\hline Variabel & p value & OR \\
\hline Umur & 0,031 & 0,031 \\
Masa Kerja & 0,004 & 0,122 \\
Beban Kerja & 0,003 & 0,000 \\
\hline
\end{tabular}

Penelitian ini juga bertujuan untuk mengetahui variabel mana yang paling dominan berpengaruh terhadap kejadian stres kerja. Berdasarkan hasil uji didapatkan hasil bahwa 54,3\% responden mengalami stress kerja tinggi dan sisanya mengalami stres kerja rendah. Pengujian terhadap variabel yang paling dominan menunjukkan hasil bahwa variabel beban kerja adalah variabel yang paling berhubungan $(\rho=$ 0,002). Variabel beban kerja bersiko 21 kali lebih banyak dalam menyebabkan stres kerja.

Penelitian lain yang dilakukan oleh Reppi dkk (2020) menunjukkan hasil yang berbeda. Faktor konflik interpersonal menjadi variabel yang paling berpengaruh pada penelitian tersebut. Terdapat perbedaan hasil yang ditunjukkan oleh kedua penelitian ini. Beberapa hal yang mempengaruhi adanya perbedaan hasil adalah pertama, variabel-variabel yang diteliti oleh kedua penelitian ini berbeda sehingga tentunya akan ada perbedaan hasil diakhir penelitian. Kedua, subjek yang dijadikan responden juga berbeda. Penelitian yang dilakukan oleh Reppi dkk menjadikan pegawai administrasi sebagai responden sedangkan penelitian ini selain pegawai administrasi juga ada tenaga medis yang menjadi mayoritas responden pada penelitian ini. Hal tersebut tentunya akan menghasilkan konflik yang berbeda, seperti beban kerja yang berbeda atau ketrampilan dalam bekerja yang berbeda pula.

\section{PENUTUP}

Kesimpulan dari penelitian ini yaitu umur, masa kerja dan beban kerja merupakan faktor yang berhubungan dengan stress kerja dan faktor yang paling dominan berpengaruh terhadap stres kerja pegawai adalah beban kerja. Berdasarkan hasil penelitian ini maka diharapkan bagi pegawai untuk bisa memahami faktor-faktor penyebab stress dalam bekerja agar bisa mencegah hal-hal yang mengakibatkan stres. Bagi Rumah Sakit untuk membuat evaluasi tentang beban kerja pegawai dan melakukan analisis beban kerja untuk menjadi acuan pembagian tugas kerja berdasarkan jabatan dan kompetensi pada masing-masing pegawai.

\section{REFERENSI}

Ariwibowo R., 2013. Hubungan Antara Umur, Tingkat Pendidikan, Pengetahuan, Sikap Terhadap Praktik Safety Riding Awareness Pada Pengendara Ojek Sepeda Motor Di Kecmatan Banyumanik. Jurnal Kesehatan Masyarakat. Vol. 2(1) Tahun 2013: 56-76

Balitbang Kemenkes RI. 2018. Riset Kesehatan Dasar; RISKESDAS. Jakarta: Balitbang Kemenkes RI

Depkes. 2009. Kategori Usia. Departemen Kesehatan Republik Indonesia 
Fitri, A, M. 2013. Analisis Faktor-faktor yang Berhubungan dengan Kejadian Stres Kerja pada Karyawan Bank (Studi pada Karyawan BMT). Jurnal Kesehatan Masyarakat FKM UNDIP. Vol. 2 No. 1 Tahun 2013.

Fuada, dkk. 2017. Faktor-faktor yang berhubungan dengan Stres Kerja pada Perawat Kamar Bedah di Instalasi Bedah Sentral RSUD K. R. M. T. Wongsonegoro Semarang. Jurnal Kesehatan Masyarakat FKM UNDIP. Vol. 5 No.5

Hamali, A. 2018. Pemahaman Manajemen Sumber Daya Manusia. Center for Academic Publishing Service.Yogyakarta.

Hariyanti., Aini, F., Purwaningsih, P. 2013. Hubungan antara Beban Kerja dengan Stres Kerja Perawat di Instalasi Gawat Darurat RSUD Kabupaten Semarang. Jurnal Managemen Keperawatan Vol. 1 No.1

Hariyati, M. 2011. Pengaruh Beban Kerja Terhadap Kelelahan Kerja Pada Pekerja Linting Manual di PT. Djitoe Indonesia Tobacco Surakarta. Skripsi Universitas Sebelas Maret Surakarta

Health Safety Executive. 2018. Work Related Stres Depression or Anxiety Statistics in Great Britain, 2018. (Online) diakses dari http://www.hse.gov.uk/statistics/causdis/stres.pdf pada tanggal 27 mei 2020

Hunter, L. W., \& Thatcher, S. M. B. (2007). Feeling The Heat: Effects of Stress, Commitment, and Job Experience on Job Performance. Academy of Management Journal, 50(4), 953-968.

Kumbadewi, L. (2016). Pengaruh Umur, Pengalaman Kerja, Upah, Teknologi dan Lingkungan Kerja terhadap Stres Karyawan. E-journal Bisma Universitas Ganesha Jurusan Manajemen. Vol 4 Tahun 2016.

Lendombela, D., J. Posangi dan J. Pondaag. 2017. Hubungan Stres Kerja dengan Kelelahan Kerja pada Perawat di Ruang Rawat Inap RSU GMIM Kalooran Amurang. e-journal Keperawatan (e-Kp). Volume 5, Nomor 1.

Mauritis, L. S. K. 2013. Selintas Tentang Kelelahan Kerja. Jakarta: Amara Books

Munandar, A. 2014. Psikologi Industri dan Organisasi. Jakarta: UI Press

Parslow, R. 2004. The impact of employee level and work stres on mental health and GP service use: an analysis of a sample of Australian governmentEmployees. BMC Public Health. (Online) http://www.biomedcentral.com/1471-2458/4/41. 20 juni 2020

Ramadhan, dkk. 2017. Hubungan Antara Persepsi Terhadap Beban Kerja Dengan Cyberloafing Pada Karyawan Biro Administrasi Umum Dan Keuanagan Universitas Diponegoro. (online). http://ejournal3.undip.ac.id/index.php/empati/article/view/15222. 2 Agustus 2020.

Reppi, B., Sumampouw, O., Lestari, H. 2020. Faktor-faktor Risiko Stres Kerja pada Aparatur Sipil Negara. Sam Ratulangi Journal of Public Health. Vol.1 No.1

Robbins SP, dan Judge. 2007. Perilaku Organisasi, Salemba Empat, Jakarta

Rumah Sakit Mata. 2019. Profil Rumah Sakit Mata Provinsi Sulawesi Utara.

Sari, D.F. (2015). Pengaruh Konflik Peran Ganda Terhadap Stres Kerja Pada Karyawan Wanita di Dinas Pertanian Provinsi Sulawesi Utara. (Online). (http://repository.usu.ac.id/bitstream/123456789/44509/4/Chapter\%2011.-pdf diakses 29 April 2020)

Sari, R,. Yusran, S., Ardiansyah, R. 2017. Faktor yang berhubungan dengan Stres Kerja pada Perawat di Ruang Inap Rumah Sakit Jiwa Provinsi Sulawesi Tenggara Tahun 2016. Jurnal Ilmiah Mahasiswa Kesehatan Masyarakat. Vol. 2 No. 6 
Sorongan, J. 2018. Hubungan Antara Stres Kerja dan Upah dengan Produktivitas Kerja pada Pegawai di Dinas Kesehatan Kota Manado. Jurnal KESMAS, Vol. 7 No. 5 (Online) https://ejournal.unsrat.ac.id/index.php/kesmas/article/view/22023

Suma'mur, P. K. 2014. Higiene Perusahaan dan Kesehatan Kerja. Jakarta: Sagung Seto

Sunyoto, D. 2015. Manajeman dan Pengembangan Sumber Daya Manusia. Yogyakarta: CAPS (Center for Academic Publishing Service).

Syabilah, C., Wahyuni, I., Widjasena, B. 2015. Faktor-faktor yang Berhubungan dengan Stres Kerja pada Penerbang Sipil di Balai Kesehatan Penerbangan Jakarta. Jurnal Kesehatan Masyarakat FKM UNDIP. Vol. 3 No. 1

Tarwaka, S. 2015. Ergonomi Industri: Dasar-dasar Pengetahuan Ergonomi dan Aplikasi di Tempat Kerja Edisi kedua. Harapan press: Surakarta-Indonesia

Tarwaka, S., H. Bakri dan L. Sudiajeng. 2014. Ergonomi untuk Keselamatan Kesehatan Kerja dan Produktivitas. Surakarta: UNIBA Press

Tarwaka. Bakri, S.H.A. Sudiajeng, L. 2004. Ergonomi untuk Keselamatan Kesehatan Kerja dan Produktivitas. Surakarta : PT UNIBA PRESS.

Yanto, A., Rejeki, S. 2017. Faktor-faktor yang Berhubungan dengan Penurunan Stres Kerja Perawat Baru di Semarang. Jurnal Keperawatan dan Pemikiran Ilmiah Nurscope. Vol. 3 No. 1

Zulkifli., R, T, Shinta., A, Sulung. 2019. Hubungan Usia, Masa Kerja dan Beban Kerja dengan Stres Kerja pada Karyawan Service Well Company PT. Elnusa Tbk Wilayah Muara Badak. Jurnal Kesehatan Masyarakat Uwigama. Vol. 5 No. 1 Pendidikan Dasar, 2(2), 120-130. 